\title{
Modeling Dialogues in FL Class
}

\author{
Albina M. Sharafieva ${ }^{1}$, Iskaner E. Yarmakeev ${ }^{1}$, Tatiana S. Pimenova ${ }^{1}$, Albina R. Abdrafikova ${ }^{1} \&$ Tatiana M. \\ Tregubova $^{2}$ \\ ${ }^{1}$ Kazan Federal University, Russia \\ ${ }^{2}$ Institute of Pedagogy, Psychology and Social Problems \\ Correspondence: Tatiana S. Pimenova, Kazan Federal University, Russia. E-mail: pimenova_ts@mail.ru
}

Received: July 17, 2019

Accepted: October 12, 2019

Online Published: October 28, 2019

doi:10.5430/ijhe.v8n7p62

URL: https://doi.org/10.5430/ijhe.v8n7p62

\begin{abstract}
The article gives a brief review on how to improve students' speaking skills via modeling dialogues in FL class. This study can be considered the continuation of the research undertaken by the authors in 2018, in which the authors put forward the hypothesis that students' speaking skills improve provided their ability to match speech patterns to behavioral patterns is developed. An aggressive behavioral pattern was researched. In this study the authors evolve that idea and analyze two more behavioral patterns: friendly and neutral. The researchers claim that the better students know different behavioral patterns, the more effectively they model dialogues. Watching videos and commenting on the conversation strategies, and modeling dialogues are chosen to be the leading teaching methods approbated in the multi-stage experiment to favor the researchers' idea. The obtained results indicate the high potential of the chosen teaching methods for the improvement of students' speaking skills in FL class and can substantially help FL teachers to adopt the most effective teaching styles, based on their course learning objectives.
\end{abstract}

Keywords: behavioral patterns, conversation strategies, FL class, modeling a dialogue, pedagogical experiment, students' speaking skills

\section{Introduction}

In this study there is presented an original way to teaching school students to model a dialogue in FL class, which, the authors assert, eventually leads to improving students' speaking skills in the foreign language. This is the second research that considers the role of the behavioral approach to teaching dialogue in FL class, with the first one being held in 2018 when the authors made an attempt to prove that students' speaking skills improve if they are able to match speech patterns to behavioral patterns. In this study the authors, developing that idea, examine friendly and neutral behavioral patterns. It is claimed that the better students get familiarized to different behavioral patterns, the more effectively they construct dialogues.

No approaches to regarding this topic have been made so far, although a great number of Russian theorists and practitioners have dealt with teaching dialogic speech issues in FL class.

The authors state that teaching school students to model a dialogue in FL class according to a certain behavioral pattern is utterly effective. With this regard, the authors set a goal to conduct a pedagogical experiment to find out in what way the knowledge of behavioral patterns can progress students' ability to model a dialogue and at large their speaking skills in the foreign language. Modeling a dialogue presupposes the knowledge of behavioral patterns, conversation strategies, and speech patterns. To know these, students are to watch videos and comment on the conversation strategies, and then model dialogues. The experiment was conducted for 48 school students during the spring semester of 2019 and had a traditional scheme: there were held an ascertaining, a formative, and a control stages. To identify the initial level of students' knowledge of different conversation strategies within the behavioral patterns, a series of diagnostic tests was held at the first stage of the experiment. The formative stage suggested watching videos and commenting on the conversation strategies. The training exercises were aimed at equipping students with the conversation strategies and appropriate speech patterns through the dramatization via the offered situations. The control experiment assessed the effectiveness of the usage of the behavioral patterns in teaching students to model dialogues in FL class.

The findings of the study display the high potential of the chosen approach to teaching modeling dialogues for the improvement of students' speaking skills in FL class and can be recommended for foreign language teachers. 


\section{Methods}

The research method in this study was a pedagogical experiment. The experimental training was conducted for school students of the 9-th grade during the spring semester of 2019. 48 students took part in the experiment: 26 students and 22 students made up a control and an experimental group correspondingly.

The experiment consisted of three stages. Diagnostic tests were held at the ascertaining stage to identify the initial level of students' knowledge of different conversation strategies within the behavioral patterns in both groups. At the formative stage watching videos and commenting on the conversation strategies they could identify and modeling dialogues were implemented in FL class. We allowed students the freedom to expand and develop ideas by immersing them into real-life situations that every person can face. Students learned conversation strategies through acting out via the situations offered by the authors. In this way, students could enjoy the competition with peers while also having fun and learning. The control experiment was carried out to assess the effectiveness of the implementation of the behavioral patterns, which, as follows from the hypothesis, should master students' speaking skills in FL class. For this, the updated diagnostic test was held. The comparative analysis of the results of the series of diagnostic tests and the updated diagnostic test was carried out.

The authors were challenged to classify three main behavioral patterns: aggressive, friendly and neutral, although in this study they analyzed two of them: friendly and neutral.

For the friendly pattern the following conversation strategies were picked out:

1. To support somebody.

2. To conduct conventional conversation.

For conversing in accordance with the neutral pattern of behavior, the following collaborative conversation strategies were offered:

1. To use personal experience.

2. To motivate somebody.

\section{Results and Discussion}

The diagnostic test held at the ascertaining stage of the experiment revealed rather a modest level of students' knowledge of conversation strategies which match the behavioral patterns.

The results of the diagnostic test are shown in Fig. 1.

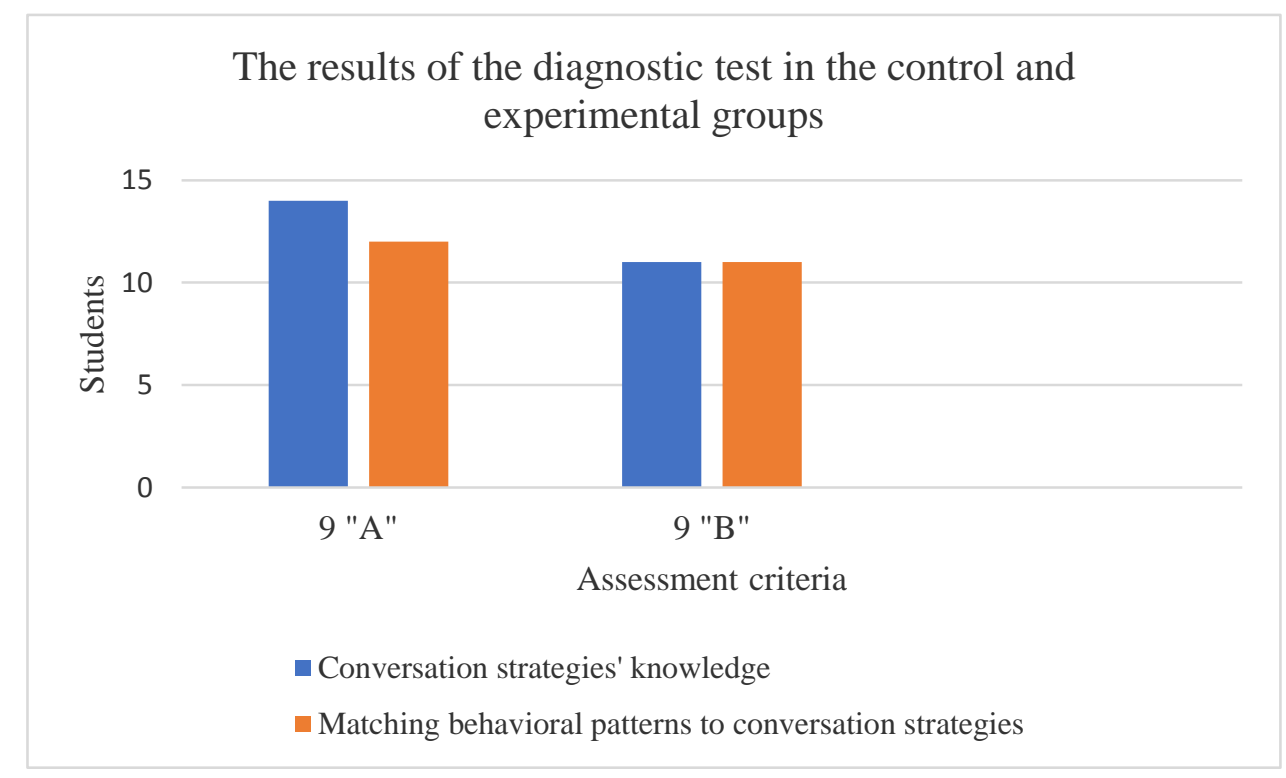

Figure 1. The results of the diagnostic test

We resorted to a number of teaching methods aimed at teaching students the relevant conversation strategies that might accompany the process of communication:

A. Watching videos and commenting on the conversation strategies 
B. Modeling dialogues

Sample

A. Students watched a series of movies of different genres where they had to predict the mood of the episode with muted sound and guess the possible conversation strategies the characters could have followed.

The following movies were selected as the basis for the formative stage of the experiment. For friendly behavioral pattern:

- "Leon" (the conversation between Mathilda and a teacher);

For the neutral behavioral pattern:

- "Friends" (the conversation between Ross and his sister Monica).

The criterion assessing the effectiveness of resorting to the movie watching can be summarized as follows:

- The number of the right answers (students had to match the behavioral pattern with an appropriate dialogue from a movie).

- The number of conversation strategies (students wrote down all conversation strategies they came across in a movie episode).

The results of the video watching criterion in the control and experimental groups are presented in Fig. 2.

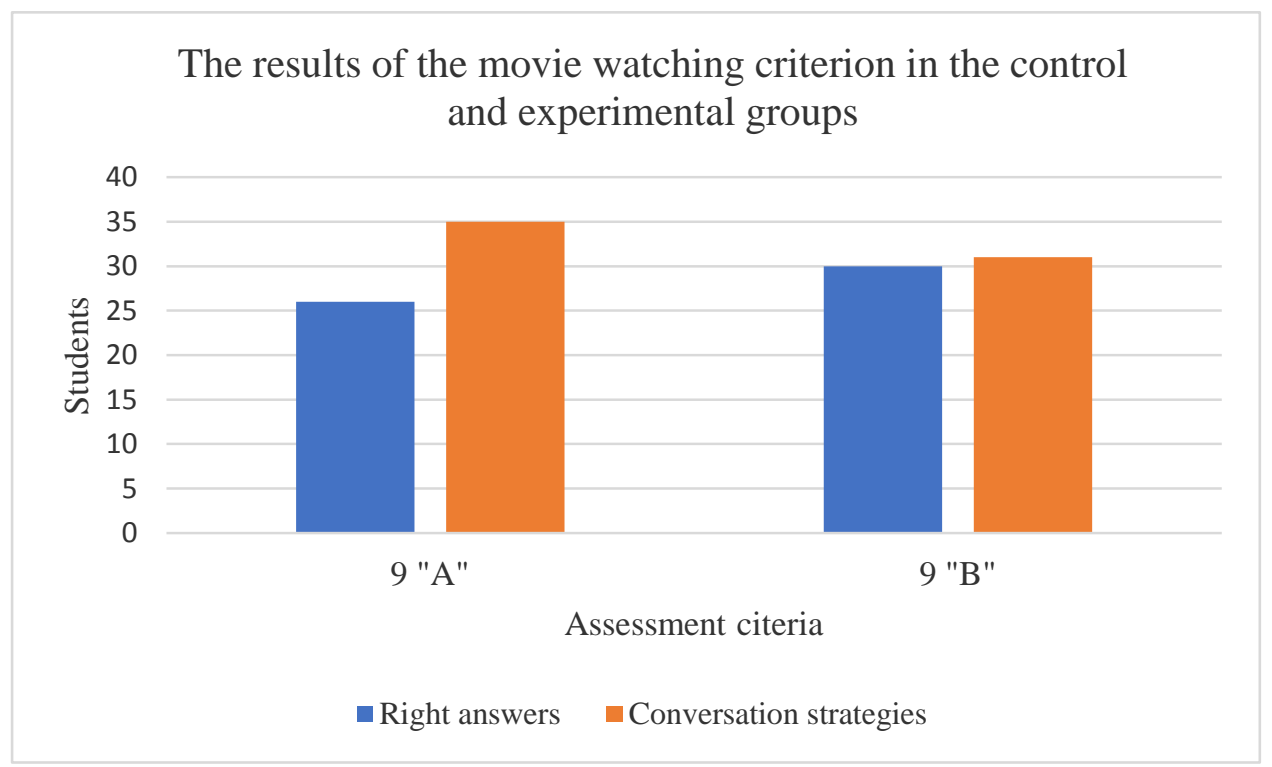

Figure 2. The results of the video watching criterion in the control and experimental groups

It is observed that this type of activity indicated relatively static figures in both groups ranging from 27 to 30 students in the right answers, and 31 to 35 students in conversation strategies.

B. A great deal of work was done to practice behavioral patterns thanks to the dramatizing and movies, but a more serious activity was modeling dialogues based on treating the discourse structure of a conversation. The ability to model and automatically detect behavioral patterns is an important step towards understanding spontaneous dialogues.

The following criteria were selected to assess the effectiveness of using dramatization in FL class:

- $\quad$ Accuracy (perfect imitation with the help of correct articulation, proper intonation, hesitation pauses etc.)

- Fluency

- Communicative skills (eye-contact, compensatory clichés)

Fig. 3 displays the students' results in using dramatization at the formative stage of the experiment. 


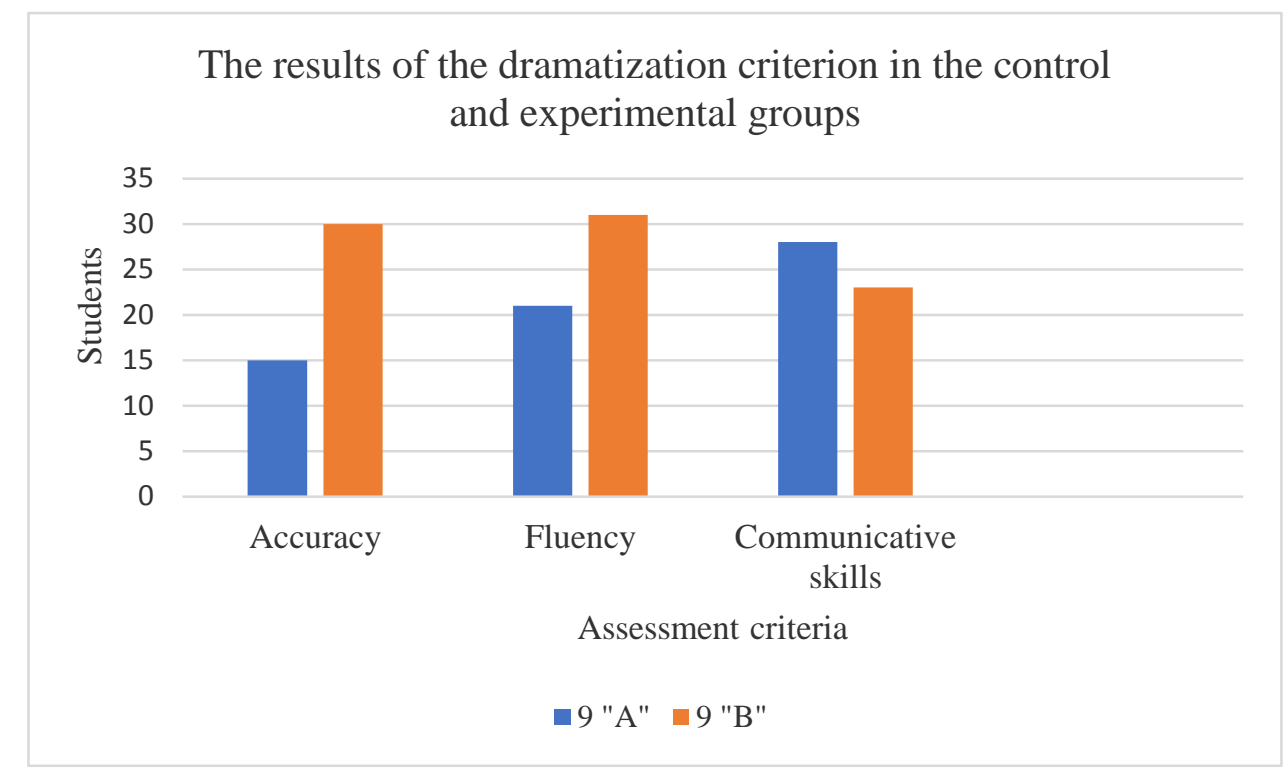

Figure 3. The results of the dramatization criterion at the first stage of the formative experiment in the control and experimental groups

As it can be seen form the graph the most developed aspect out of three can be referred to the communicative skills that amount to 28 students in the control group. However, the least successful criterion was accuracy in the experimental group reaching just 12 students correspondingly.

The last instrument as modeling included such assessment criteria as:

- $\quad$ Proper usage

- $\quad$ Fluency and accuracy combined

The results of students' modeling a dialogue in the control and experimental groups can be seen in Fig. 4.

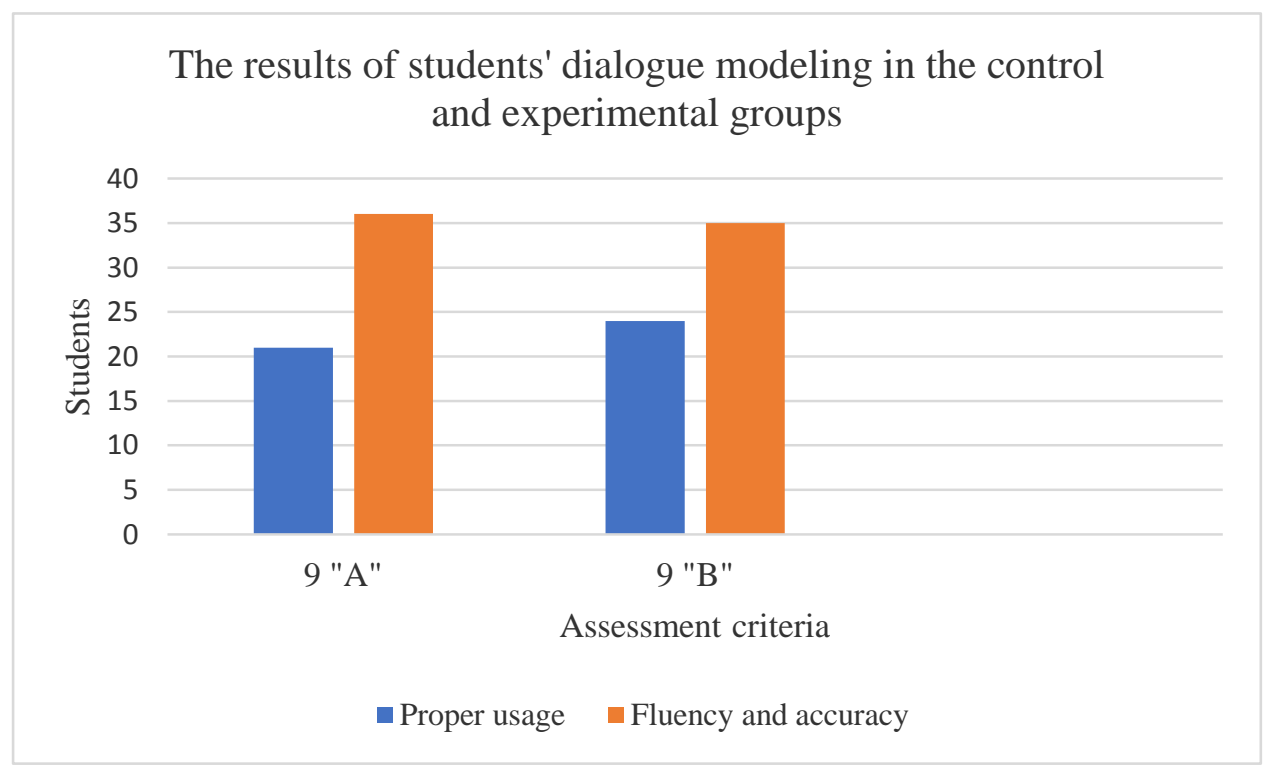

Figure 4. The results of dialogue modeling in the control and experimental groups

As it is illustrated by the graph the experimental groups showed better results in both criteria reaching approximately 31 students, whereas the control groups ranged moderately with 21 student in proper usage and 24 students in fluency and accuracy criteria. 


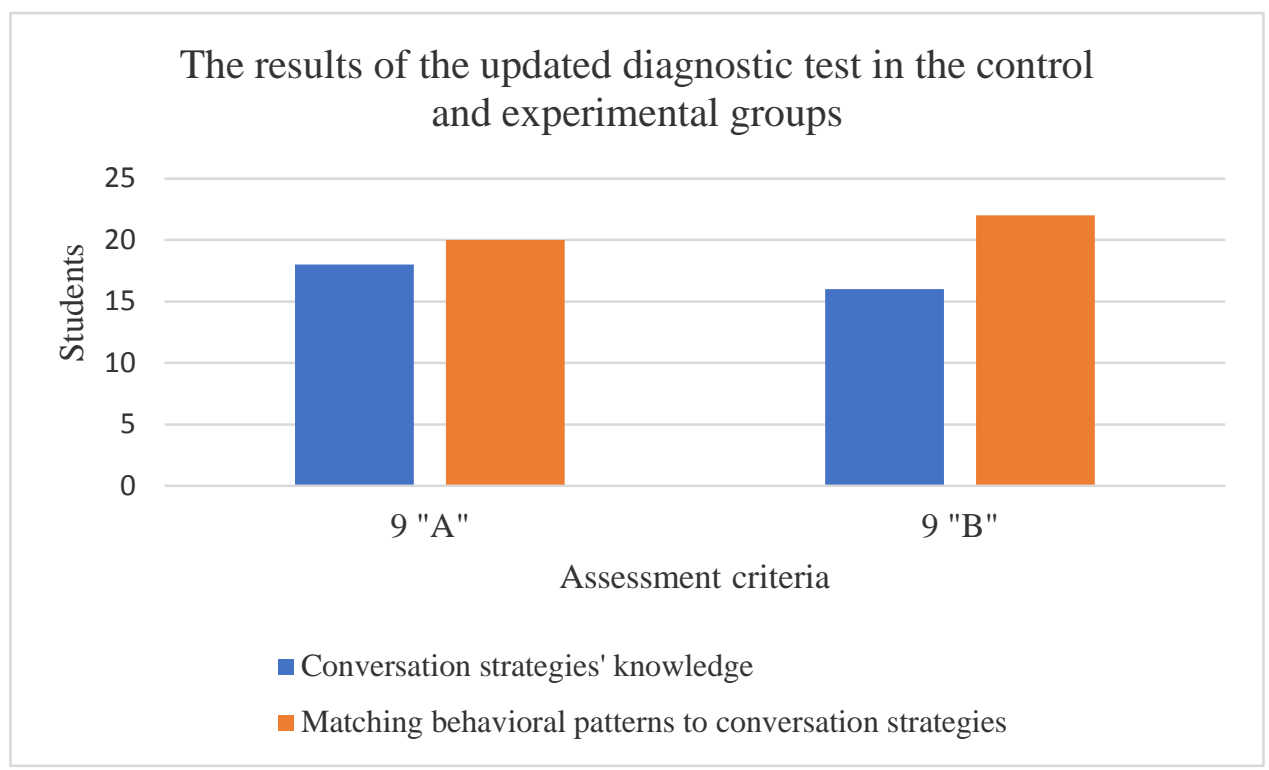

Figure 5. The results of the updated diagnostic test in the control and experimental groups

\section{Summary}

In this paper a new way of teaching dialogic speech in FL class is described. The authors state that modeling a dialogue is easy and more fun for students if they know what type of a behavioral pattern they face up to because they can choose the appropriate conversation strategy plus speech patterns to feel confident while conducting a dialogue. For this study two behavioral patterns are chosen: friendly and neutral as the aggressive behavioral pattern has already been considered at the first stage of research.

The research conducted by the authors of this study suggests that dialogue occupies a crucial position in FL class in relation to students and learning. It is not surprising that a good many Russian scholars have investigated diverse approaches to teaching dialogic speech. None, however, have considered teaching modeling dialogue in the foreign language classroom within the frame of a behavioral approach. Gez et al., Shchukin, Gorskaya Borzova, Zholnerik, Budnichenko, Agayeva, Fakhrutdinova, \& Sabirova described traditional methods of teaching dialogue in the secondary school, that is modeling a dialogue following the given dialogue pattern. Another group of scholars: Passov, $\&$ Stoyanovsky, Travkina, Weisburd, speak in favor for the use of speech situations to construct a dialogue. Although this point of view is rather close to the authors' viewpoint, it differs greatly in terms of the methodology. Milrud, Maksimova , Kazartseva, Bukicheva, Yarmakeev et al. assert that the basis for teaching dialogic speech in FL class is the communicative approach without detailing the ways of how to teach effective dialogue modeling. One more approach to teaching dialogic speech in FL class is presented by Ariyan who underlies the educational potential of speech etiquette in teaching foreign languages. Studies devoted to some psychological aspects of teaching speaking skills in a foreign language do not touch upon the behavioral approach to teaching speaking skills. The recent studies elucidate the usage of modern technologies, role-play including, in forming the communicative competence of students.

The pedagogical experiment the authors held in this study helped to highlight the beneficial effect of dialogue modeling for students' speaking skills improvement such as:

- allowing students to articulate their understanding of a topic whether it is friendly or neutral;

- enabling students to speculate through their ideas;

- assisting teachers in their understanding of 'where their students are' in their learning;

- increasing the students' awareness in modeling a dialogue according to the speaker's intention.

The outcomes of the study point out the high potential of the chosen approach to teaching dialogic speech in FL class and can serve as a guideline for foreign language teachers.

\section{Conclusions}

Our study was focused on the effectiveness of the teaching methods used by the teachers in FL class to improve students' speech fluency skill and acting abilities. This was confirmed by the results obtained from both ascertaining 
and control stages of the experiment. The findings went hand in hand with our hypothesis which emphasize that conversation strategies chosen by the authors helped the students to increase their level of achievement in speaking skills.

So, the ultimate aim of this study was to show whether it is possible to develop speech fluency of students through dialogues modeling based on the special conversation strategies. Summing up, we can say that the hypothesis put forward in this study was fully confirmed.

\section{Acknowledgements}

The work is performed according to the Russian Government Program of Competitive Growth of Kazan Federal University.

\section{References}

Agayeva, O. V. (2011). Teaching dialogic speech in EFL class. In G. D. Akhmetova (Ed.), Topical issues of pedagogy: Proceedings of the International Scientific Conference, Book I, 92-94. Chita, Russian Federation, Young scientist Publishing house. Available at: https://moluch.ru/conf/ped/archive/20/1289/ (in the Russian language).

Andrianova, N. S., Vassilieva, V. N. \& Ostroumova, O. F. (2018). Integrative use of modern technologies for teaching foreign languages, Modern Journal of Language Teaching Methods, 8(10), 271-275. Available at: http://mjltm.org/article-1-271-en.pdf

Ariyan, M. A. (1991). The use of the educational potential of speech etiquette in teaching foreign languages, Foreign Languages at School, 2, 7-8 (in the Russian language).

Bukicheva, O. A. (2006). The communicative approach to teaching dialogic speech at the initial stage in school, Foreign Languages at School, 5, 50-53 (in the Russian language).

Borzova, E. V. (1985). Dialogic speech as the purpose and means of teaching English in school (5-6 grades). Foreign Languages at School, 2, 40-43 (in the Russian language).

Budnichenko, E. P. (1991). Teaching dialogic speech in English lessons. Foreign Languages at School, 3, 58-60 (in the Russian language).

Bainiyazova, E. M., Fahrutdinova, R. A., Fahrutdinov, R. R. \& Absatova, M. A. (2017). Interactive technologies in formation of communicative competence of students of high educational institution. International Journal of Scientific Study, 5(6), 63-66. Available at: https://kpfu.ru//staff_files/F_178493122/ijss_iran_sep_17_benson_oa13.pdf

Fakhrutdinova, R. A. \& Sabirova, R. I. (2017). The development of speech skills in FL class. In O. N. Shirokov (Ed.), Development of modern education: From theory to practice: Proceedings of the International Scientific Conference, Book I, 118-119. Cheboksary, Russian Federation, Scientific Collaboration Center 'Interaktive Plus'. Available at: https://repository.kpfu.ru/?p_id=163921 (in the Russian language).

Gez, N. I., Lyakhovitsky, M. V., Mirolyubov, A. A., Folomkina, S. K. \& Shatilov, S. F. (1982). Methods of Teaching Foreign Languages in Secondary School. Moscow: High School Publishing House (in the Russian language).

Gorskaya, L. N. (1984). The initial stage of teaching dialogic speech. Foreign Languages at School, 2, 51-54 (in the Russian language).

Iravani, M. R. \& ShekarchiZade, A. R. (2014). A social work study of effective cultural, social economic factors on work stress: A Review. UCT Journal of Management and Accounting Studies, 2(1), 5-7.

Kalimullina, O. V. (2003). Role-playing games in teaching dialogic speech. Foreign Languages at School, 3, 17-20 (in the Russian language).

Mailybaev, G. S., Zhexembayeva, Z. R., Nurgaliyeva, S. A., Zholumbayeva, R. M. \& Utegulov, D. E. (2018). The efficiency of the education system in Kazakhstan: Programme for International Student Assessment (PISA). Opción, 34(85-2), 600-626.

Karaduman, E. (2013). Developing and Implementing School for Highly Gifted, Exceptionally Gifted, and Profoundly Gifted Students: An Interview with Lynette BreedLove. Journal for the Education of Gifted Young Scientists, 1(2), 53-57.

Kazartseva, O. M. (2001). The Culture of Oral communication: Training Theory and Practice. Moscow: Flinta-Nauka Publishing House (in the Russian language). 
Leontiev, A. A. (1997). Psychology of Communication: Manual for Optional Education. M.: Smysl Publishing House (in the Russian language).

Milrud, R. P. \& Maksimova, I. R. (2000). Modern conceptual principles of the communicative approach to foreign language teaching. Foreign languages at school, 4(9-15), 17-22 (in the Russian language).

Passov, E. I. \& Stoyanovsky A. M. (1989). Speech situation as a methodical category. Foreign Languages at School, 2 , $18-22$ (in the Russian language).

Shchukin, A. N. (2006). Teaching Foreign Languages: Theory And Practice. Training manual for students and teachers. Moscow: Philomatis Publishing house (in the Russian language).

Siagian, M. V., Saragih, S. \& Sinaga, B. (2019). Development of Learning Materials Oriented on Problem-Based Learning Model to Improve Students' Mathematical Problem Solving Ability and Metacognition Ability. International Electronic Journal of Mathematics Education, 14(2), 331-340. https://doi.org/10.29333/iejme/5717

Syunina, A. S., Yarmakeev, I. E., Shechter, D. A., Pimenova, T. S. \& Abdrafikova, A. R. (2017). Authentic Video Materials As A Means Of Speech Fluency Development In EFL Class. Modern Journal of Language Teaching Methods (MJLTM), 7(2), 034-040. Available at: https://kpfu.ru//staff_files/F1669006202/r_397_170917115900.pdf

Travkina, L. I. (1999). The use of the thematic reference dialogue model in teaching English. Foreign languages at school, 4, 21-23 (in the Russian language).

Weisburd, M. L. (2001). The Use of Speech Situations in Teaching Oral Speech in a Foreign Language. Obninsk: Titul Publishing House (in the Russian language).

Ugryumova, T. G. (2002). The psychological aspect of teaching FL class. Secondary Vocational Education, 5, 18-19.

Yevstigneeva, I. A. (2013). Methods of discursive abilities of students on the basis of modern information and communication technologies. (Doctoral dissertation). Available from the Russian State Library at: http://dlib.rsl.ru/01005052196 (in the Russian language).

Yakaeva, T., Salekhova, L., Kuperman, K. \& Grigorieva, K. (2017). Content and language integrated learning: Language scaffolding and speech strategies. Modern Journal of Language Teaching Methods, 7(9), 137-143. Available at: https://kpfu.ru//staff_files/F399997806/r_349_170917102337.pdf

Zholnerik, L. I. (1985). Teaching dialogic speech. Foreign Languages at School, 3, $52-55$ (in the Russian language).

Zimniaya, I. A. (1991). Psychology of Teaching Foreign Languages in the Secondary School. Moscow: Prosveshchenie Publishing House (in the Russian language).

Zimniaya, I. A. (1991). The Psychological Aspects of Teaching Speaking Skills in a Foreign Language. Moscow: Prosveshchenie Publishing House (in the Russian language). 